\title{
Borrowing Hong Kong's International Standards: A Steppingstone for the Chinese "Belt and Road" Going Out?
}

\author{
Zhiwen Gong ${ }^{1}$, Fung Chan ${ }^{2, *(1)}$ and Yan $\mathrm{Wu}^{3}$ \\ 1 School of Humanities and Social Science, University of Science and Technology Beijing, Beijing 100083, China; \\ gongzhiwen@ustb.edu.cn \\ 2 School of Social Sciences, University of Auckland, Auckland 1010, New Zealand \\ 3 Business School, University of Shanghai for Science and Technology, Shanghai 200093, China; \\ wuyanbbt@163.com \\ * Correspondence: 1cha521@aucklanduni.ac.nz
}

check for

updates

Citation: Gong, Z.; Chan, F.; Wu, Y. Borrowing Hong Kong's

International Standards: A

Steppingstone for the Chinese "Belt and Road" Going Out? Sustainability 2021, 13, 3485. https://doi.org/ $10.3390 /$ su13063485

Received: 2 December 2020

Accepted: 17 March 2021

Published: 22 March 2021

Publisher's Note: MDPI stays neutral with regard to jurisdictional claims in published maps and institutional affiliations.

Copyright: (c) 2021 by the authors. Licensee MDPI, Basel, Switzerland. This article is an open access article distributed under the terms and conditions of the Creative Commons Attribution (CC BY) license (https:// creativecommons.org/licenses/by/ $4.0 /)$.

\begin{abstract}
When the Chinese government proposed the Belt and Road Initiative (BRI)in 2015, Hong Kong was positioned as a "super-connector" responsible for bridging the mainland and global markets and was planned to integrate into the Guangdong-Hong Kong-Macau Greater Bay Area. The objective of this article is to analyze the Chinese designs to promote its BRI collaboration through Hong Kong to enhance foreign confidence and ensure that the related institutional transplantation is sustainable in other countries and that it is on par with international standards. However, the rise of neighboring cities and the changing Sino-American relationship in recent years has provided uncertainties for the future development of Hong Kong. Due to these factors, this article argues that Hong Kong may not effectively share the functions in the BRI planning designed by the Chinese authorities. Because Hong Kong's role and how it influences the policy outcomes within the BRI framework have not been thoroughly studied, this article will supplement the current literature vacuum on this specific issue and its future development.
\end{abstract}

Keywords: belt and road initiative; greater bay area; mainland China-Hong Kong relationship; transregional collaboration; institutional transplantation

\section{Introduction}

In 2015, the National Development and Reform Commission of the People's Republic of China (PRC) issued the "Vision and Actions on Jointly Building the Silk Road Economic Belt and 21st Century Maritime Silk Road (BRI Vision and Actions)" to outline the future blueprint of the Belt and Road Initiative (BRI). The whole project perceives a grand international collaboration across continents as well as oceans and emphasizes the "five areas of connectivity", which are (1) policy coordination, (2) facilities connectivity, (3) unimpeded trade, (4) financial integration, and (5) people-to-people bond [1]. In order to better implement the BRI planning, the Chinese government also proposed the Guangdong-Hong Kong-Macao Greater Bay Area (GBA) to further achieve the regional integration in the Pearl River Delta. The GBA includes the Hong Kong Special Administrative Region (SAR), Macau SAR and nine municipalities in Guangdong, among which Shenzhen and Guangzhou are the core cities. In 2017, the Guangdong Provincial Government and two SAR governments concluded the "Framework Agreement on Deepening Guangdong-Hong Kong-Macao Cooperation in the Development of the Greater Bay Area", jointly recognizing the importance of the GBA development to strengthen the BRI cooperation in the region.

As an international city, Hong Kong is assigned as a "super-connector" to establish relationships with the BRI countries by the Chinese government [2]. Under the principle of "one country, two systems", special autonomy is granted to Hong Kong that makes foreign countries view it as different to other cities in the mainland, despite the fact that the newly implemented National Security Law affected the status of Hong Kong in the eyes of Western 
countries [3]. With the current international standards and professional practices, Hong Kong will enhance the confidence of foreign investors and the sustainable governance in the process of the BRI implementation. From the perspective of perceived Chinese design, the integration into the GBA will also facilitate Hong Kong to promote the BRI planning and encourage the foreigners to enter the mainland's market through Hong Kong [4].

\section{Research Method}

\subsection{Research Question and Research Goals}

This study exhibits the role of subnational government in the BRI design and the ways of how China integrates into the globalization through the local authorities. As such, the research question is posed as the following: "What are the positive and negative factors that influence Hong Kong to become an intermediary exporting the Chinese standards to the BRI countries?" The primary goal is to analyze the opportunities and challenges for Hong Kong to achieve the BRI policy outcomes designed by the Chinese authorities. Different factors include Hong Kong's internal development, the supports and competitions from the mainland, and the development of international relations. The secondary goal is to examine how Hong Kong as a subnational unit contributes to the sustainable development in the BRI implementation. Because the Chinese government emphasizes the importance of sustainable values in the BRI polices, the international standards and professional practices of Hong Kong are employed to facilitate the sustainable development in the process of transplanting the Chinese standards into various international projects.

\subsection{Data Collection}

This study is set as an exploratory research by nature and employs a qualitative approach to address the research question. The secondary data, including but not limited to the documents from governments, international organizations, and commercial sectors, are scrutinized and most of these sources can be accessed by the internet. Because the BRI and its various polices are still in planning stage, the government addresses both from the Chinese and Hong Kong officials provide important messages for the directions of future development.

\subsection{Findings and Results}

As shown in Figure 1, this article proposes the model of Hong Kong's role in the transplantation of Chinese standards for the BRI. Through the GBA framework signed by the three governments, we concluded that the Chinese standards, such as mutual recognition of professional licenses, are transplanted into Hong Kong under the regional integration scheme. In this process of institutional transplantation, Hong Kong absorbs the Chinese standards and modifies them to be more acceptable to the foreign countries. With the established reputation in the international community, as found in various policy addresses of the Hong Kong Government, Hong Kong can promote the Chinese standards in the BRI implementation through the para-diplomatic practices.

However, due to the rise of other cities in the GBA, there are possibilities that the status of Hong Kong may be replaced or minimized in the coming future. For example, as shown in the outlines formulated by the Shenzhen Government, Qianhai transplanted Hong Kong's administrative structure, legal systems and anti-corruption organization into its new special zone. This practice also shows a para-diplomatic phenomenon in which the subnational authorities compete for resources from the central authorities in order to become more influential actors in the international activities. The downgrade of Hong Kong's status is also reflected by the top Chinese officials' speeches. In addition to the recent political development in Hong Kong, more locals contain negative sentiments towards the mainland China and the integration with Guangdong. The Sino-American relationship also increased the certainties of Hong Kong employing the para-diplomatic practices to promote the BRI implementation. These are concluded by the close observations towards the recent development in Hong Kong, the new National Security Legislation enacted by 
China, and the changes of American policies. This article argues that although China has designed Hong Kong to be a "super-connector" for the BRI, the city may not leverage its own advantages for the national strategies. Table 1 shows the positive and negative factors that influence the role of Hong Kong in the BRI implementation and examine how the two theoretical implications (i.e., institutional transplantation and para-diplomacy) link with the empirical content.

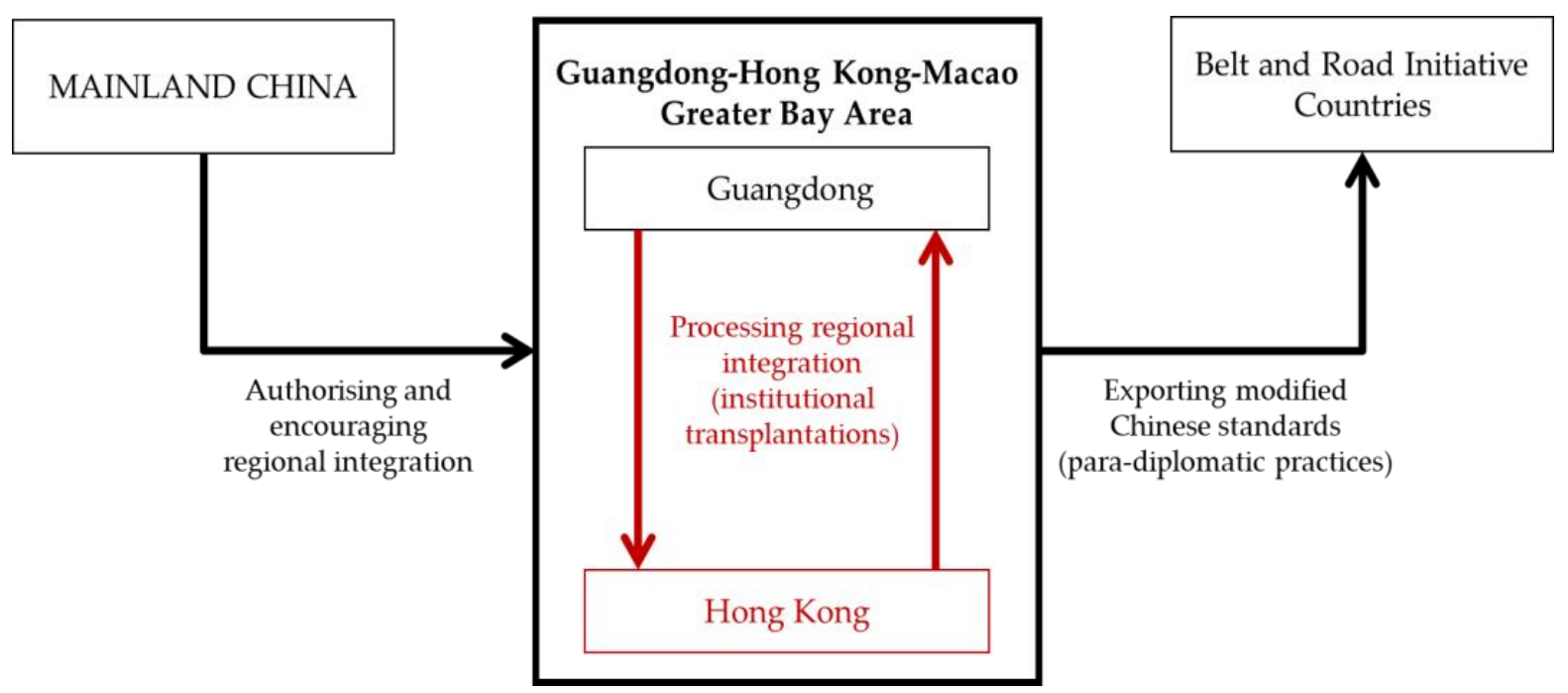

Figure 1. Role of Hong Kong in the transplantation of Chinese standards for the Belt and Road Initiative (BRI).

Table 1. Factors influencing Hong Kong to be an intermediary in the BRI.

\begin{tabular}{ccc}
\hline Factors & $\begin{array}{c}\text { Hong Kong/International } \\
\text { Factors }\end{array}$ & China Factors \\
\hline Positive & $\begin{array}{c}\text { Implementing the } \\
\text { Anglo-Saxon legal system } \\
\text { under the "One Country, Two } \\
\text { Systems" to promote the BRI } \\
\text { policy and enhance foreign } \\
\text { investors' confidence } \\
\text { (Para-diplomacy) }\end{array}$ & $\begin{array}{c}\text { Processing the regional } \\
\text { integration under the GBA } \\
\text { (Institutional transplantation) }\end{array}$ \\
\hline Negative & $\begin{array}{c}\text { Affected by the internal } \\
\text { instability and the } \\
\text { Sino-American relationship } \\
\text { (Para-diplomacy) }\end{array}$ & $\begin{array}{c}\text { Competing with other cities in } \\
\text { the mainland (Institutional } \\
\text { transplantation) }\end{array}$ \\
\hline
\end{tabular}

Source: Authors.

\section{BRI Development, Institutional Transplantation, and Para-Diplomacy}

Because the BRI was proposed in 2015, a solid pile of literature has accumulated on the Chinese national interests and its international relationship with other parts of the world. Winter considered that China is borrowing the concept of the ancient Silk Road to promote regional and continental connectivity in the modern context [5]. The BRI projects of crossborder infrastructures has also largely enhanced the Chinese international images and soft power [6]. Leverett and $\mathrm{Wu}$ provided two views on the BRI future development-(1) the Chinese project is propelled by the economic and domestic political needs which attempt to achieve a "win-win" relationship of mutual respect between China and Eurasian countries; (2) the planning is reflecting a strategic agenda for marginalizing American power in Asia and reinforcing the Chinese regional hegemony. The BRI also marks the Chinese diplomacy strategy turning to become more "proactive" and "self-achieving" (fenfa youwei) [7]. 
Although the BRI outlines the grand blueprints of international cooperation across several continents, many scholars underline the challenges caused by the existing regional complexities. Tong and Zheng argued that there were not many changes in the trade relationships among different regions and no significant growth of the trade volume due to the BRI planning [8]. Sun et al. also noted that no significant improvement of the GDP per capita was found in the selected BRI countries [9]. Zhao mentioned that although the BRI will bring economic opportunities to Southeast Asia, the negative factors, including territorial disputes in the South China Sea and disunity among the ASEAN members, might slow down the expected development [10]. Baark found that the different attitudes towards the Central and Eastern Europe made the EU countries perceive the BRI projects as a "divide and rule" strategy employed by China, which increasingly influenced the EU unity [11]. Evron considered that the BRI proposing to implement connectivity infrastructure projects would inevitably drag China into the troubled water of Middle Eastern politics [12]. As such, China needs to demonstrate the BRI advantages to the world through more subtle strategies.

This study also presents the concept of institutional transplantation to analyze China's motive of the BRI implementation. Mamadouh et al. considered that the motives of transplantation are to improve the host society and that borrowing others' institutions speeds up development at lower costs [13]. As Dequech noted, from the behavioral and mental dimensions, institutions include the patterns followed in the past and the actual rules [14]. De Jong and Mamadouh categorized the institutional transplantation into three levels (from high to low-constitutional, policy areas, and operational) and further divided each level into formal relation (legal and administrative structure) and informal practice (culture); while the higher level of transplantations is more demanding, the informal practice is more complicated to implement [15]. More transplantations or institutional borrowing are also found inside the same family of nations which shared common features and characteristics [16]. The current administrative and legal systems of Hong Kong containing the Anglo-Saxon features were inherited from the family of the British Commonwealth during the colonial period. While the mainland attempted to modify Hong Kong through the regional integration, the localities in the mainland also imitated Hong Kong's institutions to promote the BRI. From the view of the mainland, the Anglo-Saxon systems in Hong Kong contained the advantages to get connected to the international community. As Macaes considered, the BRI planned to build a new world order to transform the Washington consensus to the Beijing consensus [17]. In recent years, China also transplanted its "Shenzhen model" through establishing the Special Economic Zones in the developing countries [18]. However, before the full recognition of the Beijing consensus in the international community, the mainland needs to borrow Hong Kong's institutions to enhance the international confidence towards the BRI.

Before introducing the concept of subnational diplomacy, the perspective of sustainability in the BRI-related literatures should not be neglected. From the view of environmental conservation, the Chinese government proposed the bright future of the green economy brought by the Green Silk Road Economic Belt, providing opportunities for international environmental governance [19]. Menhas et al. also found that the locals in some BRI regions agreed that the projects initiated by China largely achieved the sustainable development [20]. However, although China has launched the domestic program of "ecological civilization", which attempts to enhance environmental regulations and adopt green technology, whether such Chinese environmental practices would be adapted to the international projects is still unknown; and because the current phase of the BRI is limited to strategizing and planning, the rules of game proposed by China have not yet been finalized [21]. A comment in Nature Sustainability shares the similar view that the environmental impacts brought by the BRI rely heavily on how China promotes the international standards [22]. Hanlon noted that the sustainability guidelines set by the Asian Infrastructure Investment Bank are similar to other international financing institutions and China cannot evade promoting the sustainability while implementing the BRI 
projects; but there was still skepticism expressed by the international community [23]. These suggested that more studies should analyze the sustainability from the perspectives of local stakeholders at a micro-level [24].

Another important angle of the BRI-related literatures is the policy sustainability. Chen et al. constructed the Financing Needs Index for the BRI to gauge the financial needs among 56 countries; and because the majority of the BRI countries are not developed economies and contain small equity markets, this makes them rely more on loans to finance their projects [25]. Especially in some developing areas, the public governance cannot ensure the necessary transparency in the process of policy formulation; and the general public in those countries might consider that the BRI-related projects were costly and could cause them stumble into the debt trap set by China [26]. Although Lai et al. noticed that there was a dissemination of debt trap concept which portrayed China's BRI aids as the strategies of controlling others' economies [27], Brautigam and Gallagher found that the Chinese finance in Africa and Latin America were operated with reasonable interest rates [28]. Liu et al. argued that the financing model is essential for the sustainability of the BRI projects and China should strengthen the cooperation with the international financial institutions in order to achieve good financial practices [29]. In this way, the Chinese government positions Hong Kong, which has already developed into an international financial center, as a "super-connector" in the BRI planning [2]. As Hong Kong has been an open and international city because of the colonial period, the foreign countries have more experience in businesses and social exchanges with Hong Kong than the mainland. Through its established international practices, the confidence will be enhanced among the BRI countries and the sustainability of the related projects will be guaranteed to a certain level.

Employing Hong Kong's advantages actually is a typical example of subnational diplomacy or para-diplomacy. The term "para-diplomacy" appeared in the 1980s to describe the international involvement of non-central governments [30]. Broadly speaking, the para-diplomacy is the establishment of permanent or temporary connections between domestic local governments and foreign public and private institutions in order to promote political, socioeconomic and cultural affairs [31]. Keating also observed that the rise of para-diplomacy was due to the globalization of the economy and communication which allowed the subnational governments to share more responsibilities [32]. Especially in the United States, the political freedom granted to the states encourages the subnational entities to pursue their interests internationally [33].

In recent years, more literature has focused on the subnational actors addressing the global sustainable development. Happaerts found that some regions took the global sustainability as their greatest priority and the preferences were not directly related to the degree of autonomy from the upper authorities [34]. Meanwhile, Plagemann and Destradi noticed that the subnational involvements in the international affairs may generate the "soft sovereignty", in which the central government devolves power to the actors below in order to strengthen the governance status in the international system [35]. From another perspective, the case of Russia's northwestern municipalities also proved that the collaborations in the sustainable development with the neighboring countries created a positive image for the country [36]. All in all, the para-diplomacy facilitates to establish multilayer and pluralistic connections among two or more regions for achieving higher international collaboration $[37,38]$.

For China, since the 1980s, the decentralization policy had empowered the provincial governments, especially in coastal areas, to have more freedoms to engage in economic cooperation with foreign actors [39]. Liu and Song proposed two important analytical lenses for examining the Chinese para-diplomacy - the analysis of the authority given from the central authorities to the localities and the analysis of the local authorities' capacity on influencing the international environment [40]. In the BRI implementation, China has employed the strategies of para-diplomacy to promote the international projects. For example, the provinces of Heilongjiang, Jilin and Liaoning showed their capacities of 
extending their influence on the Arctic where China built the Polar Silk Road as a part of the BRI [41]. Mierzejewski also found that Guangdong and Guangzhou were having a clear specialization in establishing international connections for the BRI and were reflecting collaborations among different localities; while the former was responsible for lobbying activities of joint projects in foreign countries, the latter built up the relationships with its sister cities in the BRI regions [42]. However, whether the local governments can enhance their influence through the BRI implementation depends on the decisions from the central government, sometimes leading to competitions of central resource. Summers noticed that Yunnan aimed to become an "influencer" of the national policy [43], but Liu and Song considered that the central government employed stability-oriented approach on the province and confined its influence within the region while granting more authority to Guangdong [44].

Although the Hong Kong Government does not contain a unified department responsible for its external affairs, the para-diplomatic practices are employed to radiate the city's positive influence in the international arena, including the establishments of oversea Economic and Trade Offices, the frequent official visits to other governments, the participations of international conferences with the name of "Hong Kong China", etc. [45]. Meanwhile, the Chinese government from time to time took the advantages of Hong Kong's international identity to achieve its diplomatic aims. One of the typical examples is that the Hong Kong local, Margaret Chan, represented the PRC to run in the 2006 election of the Director-General of the World Health Organization and became the first Chinese figure to lead an important international organization [46]. In this study, the para-diplomacy is defined as the subnational authorities' activities which are used to influence foreign stakeholders and facilitate the national government to reach goals in the international environment. Similar to other provinces in China, Hong Kong has its own part in the contribution to the BRI national policies. The later part of this article will analyze the role of Hong Kong assigned by the Chinese authorities in the BRI and will see how the city can or cannot use its subnational advantages to assist China to achieve the designated policy outcomes.

\section{Role of Hong Kong in the BRI}

Since the "reform and open door" policy in the 1980s, Hong Kong had been an essential stakeholder contributing to the economic development in the mainland China [47]. While Hong Kong's capitalists moved manufacturing plants to the Pearl River Delta in order to cut production cost, the business management was kept in Hong Kong to reach out to the international market. This model of specialization was known as "front shop, back factory", which was the preliminary integration between the mainland and Hong Kong [47]. After resuming the sovereignty of Hong Kong, the PRC allows the city to preserve its original British-style political, legal and social systems and implements the principle of "one country, two systems". The central government grants to the SAR Government the enjoyment of a high degree of autonomy and the maintenance its judicial and customs jurisdiction. The establishment of the SAR facilitated to increase the confidence of international investors who would deem Hong Kong to be different from other cities in the mainland.

In 2003, Hong Kong underwent a great impact on economic performance due to the outbreak of severe acute respiratory syndrome (SARS), leading to the low popularity towards the newly established SAR Government. In order to stabilize public confidence, the central government and the SAR concluded a free trade agreement, the "Closer Economic Partnership Arrangement (CEPA)" [48]. The agreement changed the model of regional integration from business-oriented to government-oriented, implying that Hong Kong would be gradually involved in the national planning by the Chinese government. The arrangements allowed the Hong Kong investors to set up their businesses with fewer restrictions than imposed on foreign capitals, while the licenses of some professional sectors (e.g., accountants, lawyers, engineers, etc.) were recognized and used for practices in the mainland. 
However, there were various difficulties in the CEPA implementation due to the localities' protectionism. The local governments were worried that the influx of investments and professional services might harm the counterparts in their jurisdictions [48]. Although the central government agreed to implement the CEPA across the whole country, only few localities had interests in attracting the business sectors from Hong Kong [48]. Until 2015, when the GBA has been proposed under the BRI framework, Hong Kong was repositioned as a "super-connector" with the international arena [2].

\subsection{Hong Kong Government's Works on the BRI}

Since the release of the BRI Vision and Actions in 2015, as shown in Table 2, the Hong Kong Government has included the BRI content in its annual policy address [49]. In 2016, the government established a steering committee responsible for formulating the strategies for Hong Kong involving the BRI. The committee is directly chaired by the Chief Executive, reflecting the high degree of the importance attached to the BRI issues inside the government. The Belt and Road Office under the committee was also set up to conduct pre-feasibility studies and coordinate the works among different governmental departments and other organizations. The office liaised with the counterparts and various business sectors in the mainland at the central and local levels.

The Hong Kong Trade Development Council also holds the Belt and Road Summit in the city annually. Over one thousand participants, including project owners and operators, investors, and services providers (e.g., banking and financial, legal, accounting, business management consulting services, etc.) from various BRI countries attended the summit every year [50]. The summit serves as an important platform for Hong Kong to build up the BRI networks and strengthens the role as an international connector. In 2017, the National Development and Reform Commission and the Hong Kong Government concluded the "Arrangement for Advancing Hong Kong's Full Participation in and Contribution to the Belt and Road Initiative", which outlines Hong Kong's pivotal position in the BRI promotion for the whole country. The formal institutional establishment between the central government and Hong Kong was initiated when the Belt and Road Joint Conference took place in Beijing in June 2018. With Hong Kong's top officials and various ministerial level units included in the joint conference, the SAR built a direct communication with the central government on the BRI issues [49].

For the purpose of fostering "people-to-people bond" with the BRI countries, the government injected 1 billion HKD to provide a targeted scholarship scheme. Hong Kong contains world-class universities which use English as the medium of language and attracts international students across the world. On the one hand, providing scholarships to the top students from the BRI countries will allow them to build up long-term relationships with Hong Kong and the mainland. On another hand, the local students will have chances to get more familiar with the BRI students through daily campus life. The government also initiated a funding scheme to support the local young people to participate exchange activities in the BRI countries. These measures nurture local talents to become the "super-connectors" in the future and employ the para-diplomatic means to enhance the images of Hong Kong and the mainland.

Table 2. Main points of the BRI implementation in Hong Kong's policy addresses.

\begin{tabular}{ll}
\hline Years & \multicolumn{1}{c}{ Content } \\
\hline & $\begin{array}{l}\text { Strengthening the status of international legal and dispute } \\
\text { resolution services under the national 13th five-year plan } \\
\text { Establishing the "Mainland and Hong Kong Belt and } \\
\text { Road Task Group" with the Ministry of Commerce } \\
\text { Studying the business opportunities from the BRI overseas } \\
\text { Economic and Trade Co-operation Zones for Hong Kong }\end{array}$ \\
\hline
\end{tabular}


Table 2. Cont.

\begin{tabular}{|c|c|}
\hline Years & Content \\
\hline 2018 & $\begin{array}{l}\text { Deepening the implementation of } 26 \text { collaboration } \\
\text { measures stated in the arrangement with the National } \\
\text { Development and Reform Commission } \\
\text { Establishing direct communication mechanism with the } \\
\text { central departments through the Belt and Road } \\
\text { Joint Conference }\end{array}$ \\
\hline 2017 (October) & $\begin{array}{l}\text { Reinforcing the manpower for the Belt and Road Office } \\
\text { Entering into the "Arrangement for Advancing Hong } \\
\text { Kong's Full Participation in and Contribution to the Belt } \\
\text { and Road Initiative" with the National Development and } \\
\text { Reform Commission }\end{array}$ \\
\hline 2017 (January) & $\begin{array}{l}\text { First proposing the role of "super-connector" in the } \\
\text { policy address } \\
\text { Organizing the "Belt and Road Summit (Hong Kong)" } \\
\text { with the Trade Development Council } \\
\text { Attending the "Belt and Road Forum for International } \\
\text { Co-operation" hosted by the central government } \\
\text { Launching the "Professional Services Advancement } \\
\text { Support Scheme" to promote Hong Kong's professional } \\
\text { services to the BRI countries } \\
\text { Launching the "Funding Scheme for Exchange in Belt and } \\
\text { Road Countries" for local young people }\end{array}$ \\
\hline 2016 & $\begin{array}{l}\text { Expressing the intention to join the Asian Infrastructure } \\
\text { Investment Bank } \\
\text { Establishing a platform for the development of } \\
\text { Islamic finance } \\
\text { Setting up more Economic and Trade Offices in the } \\
\text { BRI countries } \\
\text { Increasing the number of offers under the scholarship } \\
\text { targeting to the BRI students } \\
\text { Setting up a steering committee and the Belt and } \\
\text { Road Office }\end{array}$ \\
\hline
\end{tabular}

Source: Belt and Road Initiative Hong Kong.

\subsection{Hong Kong's Contributions on the BRI}

Some preliminary thoughts have been formed on how Hong Kong capitalizes on its unique advantage to contribute to the BRI development, and there are four general scopes: (1) international project financing, (2) offshore Renminbi business, (3) professional services, and (4) economic and trade co-operation [49]. For the international project financing, the Hong Kong Monetary Authority (HKMA, the central bank of Hong Kong) established the Infrastructure Financing Facilitation Office (IFFO) in 2016 to facilitate infrastructure investments and the related financing projects [51]. The HKMA claimed that the amount of funding needed for infrastructure in the Asian emerging regions would be around 62 trillion HKD in the 2010s, which provided tremendous opportunities for financing projects. The IFFO is designed to serve as a platform for information exchange among different stakeholders in the infrastructure investments, including but not limited to private equity funds, sovereign wealth funds, and banks [52]. As an international financial center in Asia, Hong Kong has been a cluster of various financing organizations. While the platform contributes to the infrastructure financing projects for the BRI countries, it also facilitates the institutional investors to explore new arenas of investment opportunities.

As for the offshore Renminbi business, with the proximity of the mainland, Hong Kong, ahead of Singapore, London and New York, is the currently the largest center for offshore Renminbi business. In additional to the peg to the US dollars under the linked exchange rate system, Hong Kong maintains a stable environment for its own currency and 
the foreign exchange market. Because Renminbi is not a freely convertible currency due to the foreign exchange control in the mainland, the large amount of transactions need the foreign exchange services provided in the offshore Renminbi center. As shown in Table 3, over $60 \%$ of the mainland's inward direct investment and outward direct investment was operated via Hong Kong. The city also contains the largest Renminbi liquidity offshore pool amounting to over 600 billion yuan. Different financial institutions based in Hong Kong have already introduced diversified Renminbi derivatives trading and bond products. The "Stock Connect with Shenzhen (Shengangtong) and Shanghai (Hugangtong)" and "Bond Connect (Zhaiquantong)" also establish unique channels for foreign investors to access the mainland's market through Hong Kong [53].

Table 3. Flow of China's inward and outward foreign direct investments via Hong Kong.

\begin{tabular}{|c|c|c|c|c|c|c|}
\hline \multirow[b]{2}{*}{ Year } & \multicolumn{3}{|c|}{ Inward (Billion USD) } & \multicolumn{3}{|c|}{ Outward (Billion USD) } \\
\hline & $\begin{array}{l}\text { Hong } \\
\text { Kong }\end{array}$ & World & $\%$ & $\begin{array}{l}\text { Hong } \\
\text { Kong }\end{array}$ & World & $\%$ \\
\hline 2011 & 70.50 & 123.99 & 56.9 & 35.65 & 74.65 & 47.8 \\
\hline 2012 & 65.56 & 121.07 & 54.2 & 51.24 & 87.80 & 58.4 \\
\hline 2013 & 73.4 & 123.91 & 59.2 & 62.82 & 107.84 & 58.3 \\
\hline 2014 & 81.27 & 128.5 & 63.2 & 70.87 & 123.12 & 57.6 \\
\hline 2015 & 86.39 & 135.58 & 63.7 & 89.79 & 145.67 & 61.6 \\
\hline 2016 & 81.47 & 133.71 & 60.9 & 114.23 & 196.15 & 58.2 \\
\hline 2017 & 94.51 & 136.32 & 69.3 & 91.15 & 158.29 & 57.6 \\
\hline 2018 & 89.92 & 138.31 & 65.0 & 86.87 & 143.04 & 60.7 \\
\hline 2019 & 96.30 & 141.23 & 68.2 & 90.55 & 136.91 & 66.1 \\
\hline
\end{tabular}

Source: Ministry of Commerce, the People's Republic of China (PRC).

For the professional services, Hong Kong is well-known for its services-oriented economy constituting over $90 \%$ of the local GDP. More than 227,000 people engage in various professional services including but not limited to legal, accounting and auditing, architecture and engineering, and information technology sectors [54]. With the experience of the engineering project management in the partnerships with the mainland and international infrastructure organizations, Hong Kong is also equipped with the necessary talent pool to provide consulting and managing services for large-scale projects in the BRI countries. The oversea investors will enjoy the one-stop service provided by Hong Kong's professional sectors ranging from city-planning, architectural design, and builder and contractor management to legal consulting, insurance arrangement, and real estate management. Lastly for the economic and trade co-operation, Hong Kong has been a logistics services hub and a regional trading center for long [55]. The aboard distributors of both commodity and luxury goods find outlets in the local or the mainland markets via Hong Kong. Due to the geographical position as a hub between the mainland and the West, Hong Kong's local market is also serving as an ideal testing place for various foreign products before entering the mainland. The city, in addition, facilitates the brand-name building for their goods through the advertising and marketing services provided by the local sectors. All these features of the subnational authorities maintain the positive image of Hong Kong in the international environment. From the perspective of para-diplomacy, these advantages of Hong Kong are taken by the Chinese government to achieve the national aims in the BRI planning.

\subsection{Borrowing Hong Kong's Advantages to Achieve the BRI Sustainability}

In order to arouse support in the international arena, the Chinese government emphasized the importance of sustainability in the BRI implementation [55]. During the 2019 Belt and Road Forum for International Cooperation, which took place in Beijing, the Belt and Road Initiative International Green Development Coalition (BRIGC) was formed under the supervision of the United Nations Environment Program. The BRIGC aims to ensure that the BRI investments achieve long-term green and sustainable development and fulfill 
the 2030 Agenda for Sustainable Development. The coalition is also concerned about the capacity building on sustainable infrastructure investments, which needs good governance structures to attain the expected policy goals [56]. To enhance the confidence in achieving the BRI sustainability among various countries, the Chinese government borrows Hong Kong's status, as an international metropolitan with Western standards and governance structure, to promote the BRI planning. In the 2019 policy address of Hong Kong, the government stated that it will work closely with the central government to "realize the goal of open, clean, green and sustainable BRI development" [49].

Apart from providing a platform for information exchange on infrastructure investments, the mission of the IFFO includes "facilitating investments and financing of sustainable infrastructure and green development". To this end, the IFFO in May 2019 also set up the Centre for Green Finance (CGF) to strengthen the status of Hong Kong as the hub of green finance in Asia [51]. The Organization for Economic Co-operation and Development estimates 6.9 trillion USD would be needed annually for green infrastructure investment until 2030. Currently, the mainland is the second largest green bond issuer sharing around $15 \%$ of the total amount in the world. In the speech made by the Chinese President Xi Jinping in the 19th Party Congress, the Chinese government has set the development of green finance as a national strategy. As such, there will be over 3 trillion RMB of annual green investment estimated in the mainland and required an international outlet to absorb the related bond products [57]. Figure 2 shows that both the volumes of China's issuing green bond with the Chinese definitions and the Climate Bonds Imitative (CBI) definitions have been rapidly increasing since 2016. Besides the mainland's domestic market, when the mainland's enterprises go out for investing infrastructure in the BRI countries or the BRI countries seek for gateways of financing projects, the supply for green investment products will definitely increase in the foreseeable future.

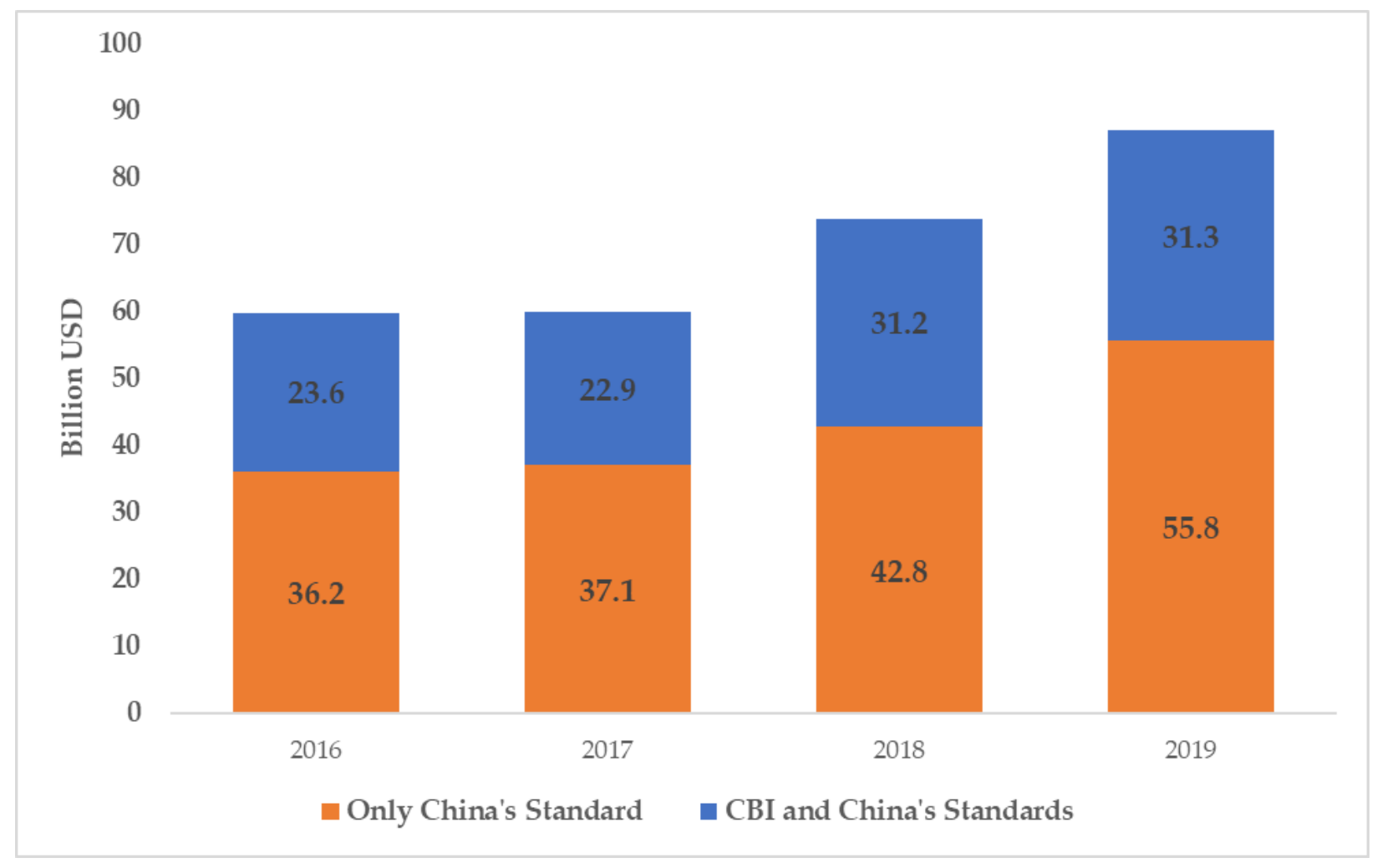

Figure 2. Volume of China's issuing green bond from 2016 to 2019. Source: Climate Bonds Initiative.

Moreover, the United Nations introduced the Principles for Responsible Investing in 2016 to promote sustainable investment. The environmental, social and governance 
(ESG) factors has become more important in the decision-making of investment. With the advantages of being the international financial center, Hong Kong has established a strong foundation to provide green investment services. Various internationally renowned green reviewers had deployed their branch offices in Hong Kong to facilitate the work of green products assessment, largely enhancing the confidence of the oversea green bond investors. The Hong Kong Quality Assurance Agency (HKQAA) also implements the Green Certification Scheme which certifies the green products fulfilling criterions recognized by the agency. The scheme employed both the mainland and international standards in line with on-the-ground knowledge of the mainland in the process of assessing the green products [57]. This practice facilitates the outside investors to get familiar with the mainland standards and unique circumstances while transplanting the Chinese standards into Hong Kong and the international market.

As a promoter of the ESG investing for the BRI, Hong Kong leverages on the advantages of its governance system under the "one country, two systems". With the common law system practiced in Hong Kong, the rule of law is guaranteed to the international investors. For a long period, the city's judiciary and arbitration have been well-known for international dispute resolution. The arbitration awards obtained in Hong Kong are able to be enforced in over 100 oversea jurisdictions as well as in the mainland under the New York Convention and the reciprocal arrangement respectively. To strengthen the status as an international arbitration center, the government established the "Inclusive Dispute Avoidance and Resolution Office" to promote employing arbitration as the means of resolving disputes addressing international investments [58].

Moreover, Hong Kong's corruption-free environment is appreciated by the international stakeholders. According to the Corruption Perceptions Index 2019 conducted by the Transparency International, Hong Kong is ranked 16th as the least corrupted region, while the mainland is ranked 41st only [59]. The corruption level reflects the standards of public governance and the fair environment, which are the factors most international investors are concerned about. Hong Kong is actually serving as an immediate zone between the international market and the mainland while becoming a connector for the BRI in term of international practices. This section shows how Hong Kong contributes to the BRI sustainability and how its advantages are utilized to promote the national BRI strategies from the perspective of para-diplomacy.

\section{Chinese Design-GBA Regional Integration for the BRI Preparation}

The GBA development was set as a national strategy to strengthen cooperation among Guangdong, Hong Kong and Macau in the BRI implementation. It is also the largest and most aggressive regional integration planning between the mainland and Hong Kong in order to form the bigger city cluster in the world.

\subsection{Hong Kong Integrating into the GBA}

Although the CEPA was concluded in 2003, there were not few entry problems faced by outsiders for investing in the mainland. The formulation of the CEPA was a typical topdown process in which only the top officials from the Hong Kong Government and the PRC Ministry of Commerce were involved in the negotiation. Because the local governments did not participate in the policymaking process, most of them were passively informed to implement the CEPA measures for Hong Kong's investors which might not benefit directly their respective jurisdictions. In the 2013 policy address, the Chief Executive of Hong Kong proposed to enhance "G2G (government-to-government)" for the better CEPA implementation and more concrete networks should be established between Hong Kong and provincial as well as municipalities' governments. The central government also set up a joint working group with the Hong Kong side to tackle the entry problems encountered by the small and medium enterprises from Hong Kong [60]. Still, the central government could not largely enhance the localities incentives for the CEPA implementation before proposing the GBA development. 
As a matter of fact, the CEPA is an essential showcase for the economic cooperation with the place outside the mainland. If Hong Kong, as a PRC's special administrative region, is perplexed by the entry problems, the international investors may have more serious problems than what Hong Kong is facing. The Chinese government does need to have a better integration with Hong Kong or smoother CEPA implantation in order to gain the international stakeholders' confidence for the future BRI planning. Being different from the CEPA, the GBA is a national policy specifically involving nine municipal cities in Guangdong Province. Every city, being the important stakeholder in the GBA development, is assigned specific roles for contributing to the regional integration. As shown in Figure 3, the PRC State Council also deliberately established the Leading Group for Development of Guangdong-Hong Kong-Macao Greater Bay Area, chaired by one of the members of the Party Standing Committee Politburo and joined by the Party Secretary of Guangdong Province and two Chief Executives from Hong Kong and Macau [48]. The high-profile establishment will raise the incentives of the localities to implement the integration policy.

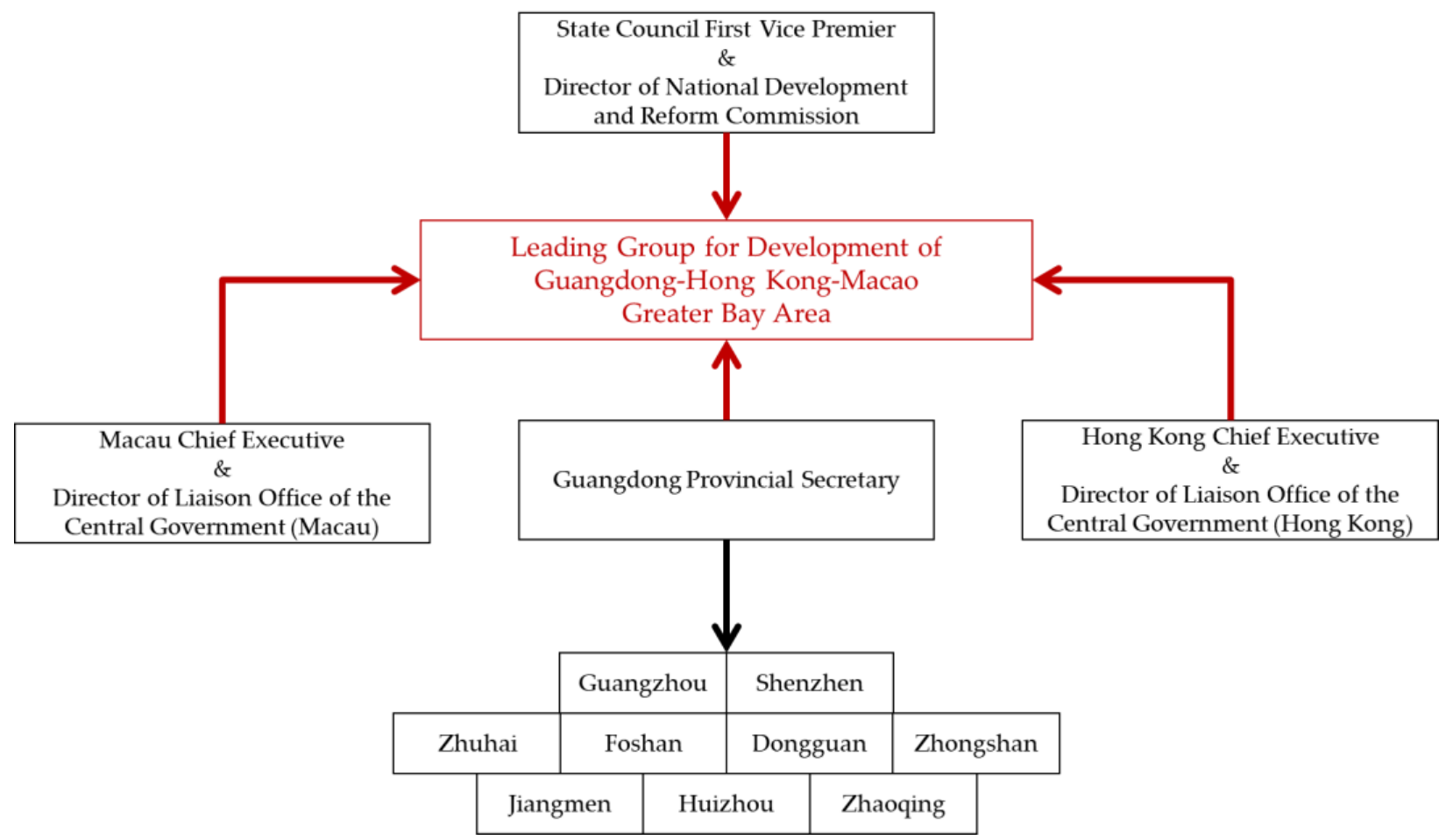

Figure 3. Centralized coordination in the Guangdong-Hong Kong-Macao Greater Bay Area (GBA) development.

In order to further break through the barriers of integration, a comprehensive national treatment was granted to the Hong Kong citizens and investors in 2018 [61]. The Hong Kong locals are entitled to apply for the PRC national resident identity card and deem as normal residents settled in the mainland. Especially for the investors, the national treatment allows them to be treated as the nationals who will not have the restrictions of ownerships and minimum capital investment. This practice encourages more small and medium enterprises from Hong Kong to enter the mainland's market with small amounts of investment. Because the BRI is designed to establish closer relationship with other regions from all parts of the world and will increase the flow of people into the mainland, the GBA will serve as an experimental site for providing the national treatments for the outsiders. The integration between the mainland and Hong Kong under the GBA planning will be a feasibility study for the BRI from the perspective of building people-to-people bond.

One of the CEPA implementation scopes is to mutually recognize professional licenses, such as in the two sides, implying that various Hong Kong's professionals can practice in the mainland with their original licenses. Although this is the main practice of institutional 
transplantation under the CEPA arrangement, the measure is not enough to attract Hong Kong's practitioners to provide services in the mainland and vice versa. While Hong Kong's professionals are not familiar with unique environment and practices in the mainland, the mainland's ones are not accustomed to the restrictions imposed by the license authorities with the international standard. For example, the University of Hong Kong-Shenzhen Hospital is a public hospital in Shenzhen operated with the "Hong Kong standard". The doctors, who are holding Hong Kong's medical license and practice in that hospital found that the patients in the mainland kept requesting to have intravenous therapy, which was the treatment seldom used in Hong Kong [62].

The GBA development further enhances the dynamic flow of people among different cities. As a super-city cluster, the living area of the GBA residents will have no border restricted in seeking for living, education and working opportunities. More measures will be introduced to allow the Hong Kong locals to study and work in the mainland and vice versa [63]. After a certain period, people from both sides will be nurtured to be familiar with the mainland and Hong Kong under the GBA assimilated environment. On the one hand, a part of the Chinese standards or practices will be transplanted to Hong Kong through the GAB development and exported to the outside world. On the other hand, under the "one country, two systems", the establishments of the license authorities or the local governance will be maintained to sustain the Chinese influence over its original standards. In this way, the standards promoted by the Chinese authorities in the BRI may be the ones integrating the features of two places. Comparing with the direct transplantation of Chinese standards into the BRI countries, the integrated ones through Hong Kong or the GBA will be more acceptable to the foreigners. If such design succeeds in integrating the two sets of standards and practices, the utilities of para-diplomatic features of Hong Kong will be largely maximized.

\subsection{Rise of Competitions of Neighboring Areas}

Instead of putting all eggs into the integration with Hong Kong, the Chinese authorities also have backup arrangements to guarantee the smooth BRI implementation. The value of Hong Kong is relied on the degrees of openness and liberalization which are granted by the central government under the framework of the Basic Law. As long as the Chinese government is willing to further implement the liberalization policies, the advantages held by Hong Kong may be easy to be copied by other mainland's cities.

One of the examples is the planning of Qianhai New District in Shenzhen, which is known as "the special zone of the special economic zone". The district will gradually abolish entry restrictions for foreign investors on qualification criterions and scopes of business in various sectors, especially for the financial industries. Instead of using a positive list of allowing entry business, the authorities imposed a negative list that has few restrictions on the business types. Qianhai Shenzhen also provides more preferential policies than the normal special economic zones in the mainland, including but not limited to low profit tax ( $15 \%$ of tax deduction for planned corporations), comparatively free inflow and outflow of capitals, and high subsidies provided to specific enterprises or professional talents [64]. The goal of Qianhai is to establish an international financial center that has a similar capacity of Hong Kong. As such, the financial activities for foreign investors will bypass Hong Kong and directly find the necessary services in Qianhai Shenzhen.

Apart from its positioning in the GBA development, Qianhai implements the pioneering decentralization policy that delegates power to an enterprise-style statutory board-the Authority of Qianhai. The authority is empowered by the "Shenzhen Special Economic Zone Qianhai Shenzhen-Hong Kong Modern Services Zone Regulations" enacted by the Shenzhen Municipal Government with the support of the central government [65]. Qianhai has its own judiciary and legislative systems inside the jurisdiction and is exploring the feasibility of introducing the Hong Kong commercial laws. For example, the Qianhai Tribunal is running a pilot scheme which integrates the Chinese-style mediation system with the Western jury system. To handle complicated commercial disputes, a mediation 
council is set up under the structure of the tribunal. After the failures of mediation, the cases will be passed to a "People's Jury" formed by the Chinese nationals holding the Hong Kong citizenship with certain legal expertise [66]. Under such an arrangement, the locality has the expectation to establish a legal system adapting to the Chinese mechanism with the reference of the international guidelines.

For the purpose of further enhancing the international confidence on the governance system, Qianhai also has its own anti-corruption bureau which is directly accountable to the Shenzhen Municipal Committee. The bureau staff is formed by the representatives from the commission for discipline inspection, the supervision bureau, the People's procuratorate, the public security bureau and the audit bureau [66]. With such unified anti-corruption system as shown in Figure 4, the goal of the bureau is to build up an efficient mechanism to overcome the weakness of Chinese-style fragmented administration and prevent corruptive practices in Qianhai Shenzhen. Although the Qianhai Anti-Corruption Bureau is not as independent as the Hong Kong's Independent Commission against Corruption, such modern governing establishment reflects the determination of reform in the locality and the transplantation of Hong Kong's institutions. Once the investors' confidence towards Qianhai is established in the international environment, the role of Hong Kong in the BRI will inevitably be undermined.

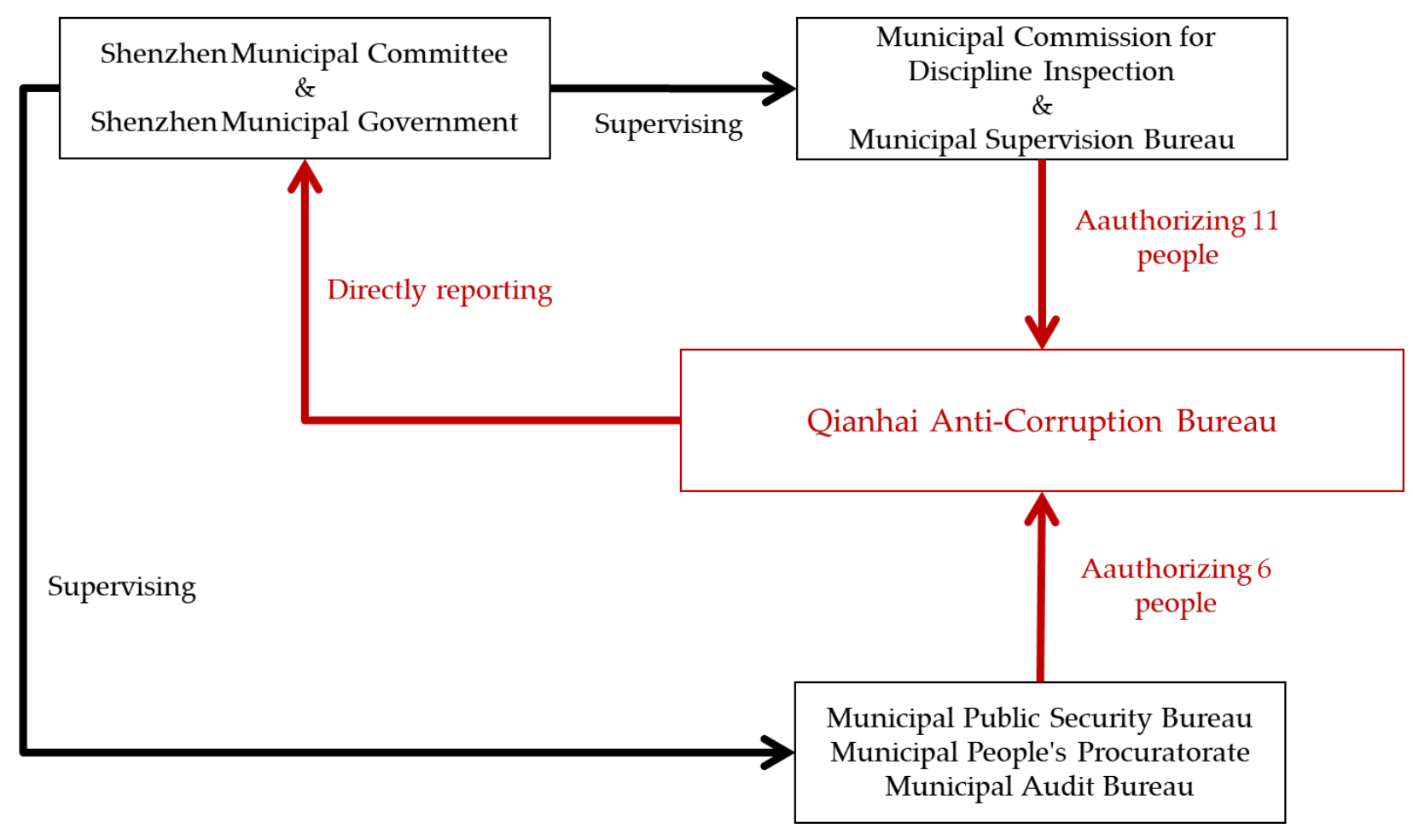

Figure 4. Model of "Unified Management of Manpower, Lawful Execution of Power and Collaborative Implementation of Supervision".

In the Chinese President Xi Jinping's visit to Shenzhen in October 2020, he confirmed that Shenzhen is serving as the core engine for the GBA and urged the city to promote integration with Hong Kong [67]. On one hand, the Chinese authorities are planning to downplay the status of Hong Kong under the GBA framework. On another hand, the mainland may directly export its Chinese standards through the newly arising areas featuring the certain senses of international practices for the future BRI. With these factors, whether the para-diplomatic advantages of Hong Kong can be leveraged is partly depended on the development of other GBA cities. This also reflects one characteristic of the Chinese para-diplomacy as mentioned before. Similar to other provinces, Hong Kong needs to compete with other localities for the resource or opportunities from the national authorities. 


\section{More Future Challenges Ahead for Hong Kong}

Whether Hong Kong largely contributes to the BRI development still contains more uncertainties than expected. Apart from the possibility of being replaced by other cities in the mainland, Hong Kong itself may not be equipped with the necessary features that can facilitate to promote the BRI. In addition to the development of the Sino-American relationship in recent years, Hong Kong has been gradually losing its original para-diplomatic advantages for the mainland.

First and foremost, although Hong Kong is an international city with huge flows of foreigners, the locals may not be familiar with the most BRI countries from South and West Asia, Eastern Europe and Africa. While Hong Kong was a British colony having close relationships with the Anglo-Saxon economies, it also has frequent business activities with East Asia and Southeast Asia due to the geographical proximity. However, Hong Kong has not nurtured a talent pool for connecting the BRI countries not coming from its traditional business partners. As mentioned previously, the Hong Kong Government provides the scholarships for the top BRI students to pursue degrees in the local universities, but the number of beneficiaries is very limited and may not establish long-term relationship with many locals. On the contrary, different universities in the mainland have provided subsidies for students from the developing regions for long, while the origins of the BRI students are more diversified than the ones in Hong Kong. The Muslim communities from some provinces in the mainland, such as Gansu and Xinjiang, also facilitate to establish trading partnerships with the BRI people. It is indeed true that Hong Kong may attract more expatriates from the Western developed countries to study or work in the city, but the BRI planning includes various countries far from Hong Kong's traditional partners.

Secondly, both the worsened Sino-American relationship and the changing Chinese policy towards Hong Kong are affecting the special status of the city. In 2019, Hong Kong underwent a year-long rioting and a series of police-citizen conflicts. In order to clamp down on the public violence, the Hong Kong National Security Law was enacted and promulgated in the city on 1 July 2020. Because the law criminalizes subversion, terrorist activities and collusion with outside forces and stipulates that the maximum penalty of committing the law shall be the life imprisonment, this seriously alerted the business sectors to the investment environment of Hong Kong [68]. To respond to the Chinese new policy, the United States issued a president's executive order to alter the differential treatment to Hong Kong. Under the Hong Kong Policy Act of 1992, the United States would not deem Hong Kong as a part of the mainland's jurisdiction due to its special autonomy granted by the Basic Law and the 1984 Sino-British Joint Declaration. The United States is now seeing the new national security law imposed in Hong Kong as a threat to the American nationals in the city. The executive order also stated that the journalists and human rights organizations would become more difficult to function in Hong Kong. As such, the United States began to eliminate differential treatment which had already given to Hong Kong and might see the city same as other Chinese places [3]. For example, the Hong Kong products exported to the United States shall be labelled "made in China", instead of "made in Hong Kong". If other Western countries follow the practices of the United States, it is inevitable for Hong Kong to lose its original features as the international city which should be deemed different from the mainland. The role of "super connector' designed in the BRI planning will be largely diminished in future.

Last but not least, a portion of Hong Kong locals contains anti-Chinese sentiment, and thus, integrating Hong Kong into the GBA may become a more difficult task than before. Since the implementation of the Individual Visit Scheme along with the signing of the CEPA in 2003, a large number of mainland visitors had gone to Hong Kong for various purposes. The influx of traders as well as tourists into the city had disrupted the daily life of many citizens, leading to the rise of radical figures proposing to politically and economically separate Hong Kong from the mainland [69]. Because such anti-Chinese sentiment may cause the negative feeling among the locals towards the BRI planning, Hong Kong advantages may not be taken for promoting the international cooperation for 
China in future. From the perspective of the mainland, most policy outcomes designed by the Chinese government can be achieved by the mainland itself. However, bypassing Hong Kong in the process of promoting the BRI may incur more cost to persuade foreign countries to accept the Chinese standards, while Hong Kong cannot serve as the immediate zone to guarantee the sustainability of the policies that China will export to the BRI countries. Whether the para-diplomatic features of Hong Kong will still be significant becomes a doubt. This may cause uncertainties and a more or less direct impact on the BRI implementation that the Chinese government should not ignore.

\section{Concluding Remarks}

This article recognizes that the role of Hong Kong in the BRI planning is to utilize its para-diplomatic features to promote the international projects and to reveal the institutional transplantation between Hong Kong and the mainland under the GBA regional integration. With the standards and professional practices inherited from the legacy of the British colony, Hong Kong enhances the confidence of foreign countries in the process of the BRI implementation. Meanwhile, the BRI will also bring various opportunities and benefits to the city, including but not limited to injecting foreign capitals through financing infrastructure projects, enhancing the status of international arbitration center and strengthening the role of the educational hub in the Asia-Pacific region. Obviously, the Chinese government employs the subnational or para-diplomatic advantages of Hong Kong under the "one country, two systems" to implement its grand BRI national blueprint. In order to more effectively influence Hong Kong or transplant the Chinese standards for the BRI development, the Chinese government set the GBA as the national strategy to encourage the regional integration between Hong Kong and Guangdong. On one hand, while the GBA will allow the foreigners to enter the mainland's market through Hong Kong, the people and capitals from the mainland will be more convenient to go out under the GBA platform. On another hand, the GBA serves as an experimental site for the Chinese international standards before adopting the related practices in the BRI projects. The successful integration of Hong Kong into the GBA will reflect the higher possibility for the outside world accepting the Chinese transplantation.

This article also proposes the various challenges ahead for Hong Kong's position in the BRI planning. In the 1980s, when the mainland implemented the "reform and open" policy, Hong Kong largely facilitated China to open itself for the world economy. To some extent, the BRI will be the second "reform and open" policy which will enhance the Chinese influence in the international arena. Different from the period of the 1980s, the BRI implementation will not be heavily relied on Hong Kong's assistance or participation. With the rise of other cities in Guangdong, the original functions of Hong Kong can be sooner or later replaced. In addition to the political instability of the city in recent years, the Chinese authorities may be more cautious towards Hong Kong's affairs and encourage other cities in the mainland to bring into line with the international standards. Even though Hong Kong will be marginalized in the planning, the BRI will go on and be maintained as the national strategy. This article argues that Hong Kong may not become the essential stakeholder in the BRI future development under the policy change of the Chinese authorities. However, without Hong Kong's established international standards, China may need to put more effort on persuading others to accept the practices with the Chinese characteristics in the BRI projects.

Another important point noted in this article is that Hong Kong may enhance the sustainability for the BRI planning. In order to solicit supports from foreign countries, the Chinese government emphasized the value of the sustainability in the BRI implementation from time to time and claimed that the past and undergoing projects had brought positive impacts on the sustainable development in various countries since the proposal of the BRI Vision and Actions [70]. A Chinese think tank also established the BRI Sustainability Index to gauge the sustainable development in terms of economic, social and conservational perspectives for the BRI countries. The index showed that the paces of related development 
in the participating member states were accelerated after 2013 and even concluded that the BRI projects had a significant contribution on the progress [71]. Having said that, the World Bank stated that the large scales and volumes of the infrastructure projects proposed in the BRI have never been experienced in the human history; thus, a wide range of environmental risks had been posed (e.g., deforestation, wildlife habitat fragmentation, hydrologic disruption, etc.) and their long-term impacts on the environment should be concerned by the world [72]. The Organization for Economic Co-operation and Development also warned that the potential debt issues caused by over-investment in the developing economies may affect the policy sustainability in the coming future [73]. Because this article is an exploratory study aiming to sort out the role of Hong Kong in the national planning, the actual degree of the impacts on sustainability is not deeply analyzed. As such, more empirical analysis of assessing the sustainability affected by the mainland and Hong Kong through the BRI implementation process is suggested for future research.

Author Contributions: Z.G. and F.C. participated in all the phases and contributed equally to this work; Z.G. and F.C. wrote Sections 1 and 3, Sections 4-6; Y.W. wrote Section 2. All authors have read and agreed to the published version of the manuscript.

Funding: This research received no external funding.

Institutional Review Board Statement: Not applicable.

Informed Consent Statement: Not applicable.

Data Availability Statement: Not applicable.

Conflicts of Interest: The authors declare no conflict of interest.

\section{References}

1. Belt and Road Initiative Hong Kong. A New Platform for Cross-Region Cooperation. Available online: https://www.beltandroad. gov.hk/overview.html (accessed on 27 November 2020).

2. Belt and Road Initiative Hong Kong. HKSARG's Policies and Strategies on the Belt and Road. Available online: https: //www.beltandroad.gov.hk/ps.html (accessed on 17 January 2021).

3. White House. The President's Executive Order on Hong Kong Normalization. Available online: https: / www.whitehouse.gov / presidential-actions/presidents-executive-order-hong-kong-normalization/ (accessed on 27 November 2020).

4. Greater Bay Area. Outline Development Plan for the Guangdong-Hong Kong-Macao Greater Bay Area. Available online: https://www.bayarea.gov.hk/filemanager/en/share/pdf/Outline_Development_Plan.pdf (accessed on 17 January 2021).

5. Winter, T. Geocultural power: China's Belt and Road Initiative. Geopolitics 2020, 1-24. [CrossRef]

6. Voon, J.P.; Xu, X. Impact of the Belt and Road Initiative on China's soft power: Preliminary evidence. Asia Pac. J. Account. Econ. 2020, 27, 120-131. [CrossRef]

7. Leverett, F.; Wu, B. The New Silk Road and China's evolving grand strategy. China J. 2017, 77, 110-132. [CrossRef]

8. Tong, S.Y.; Zheng, Y. The Belt and Road Initiative and China's trade development. China 2019, 17, 50-61.

9. Sun, Q.; Zhang, X.; Xu, X.; Yang, Q.; Wang, S. Does the "Belt and Road Initiative" promote the economic growth of participating countries? Sustainability 2019, 11, 5240. [CrossRef]

10. Zhao, H. China's Belt and Road Initiative and ASEAN. China 2019, 17, 127-147.

11. Baark, E. European perspectives on the Chinese Belt and Road Initiative. China 2019, 17, 76-95.

12. Evron, Y. The challenge of implementing the Belt and Road Initiative in the Middle East: Connectivity projects under conditions of limited political engagement. China Q. 2019, 237, 196-216. [CrossRef]

13. Mamadouh, V.D.; De Jong, M.; Lalenis, K. An introduction to institutional transplantation. In The Theory and Practice of Institutional Transplantation: Experiences with the Transfer of Policy Institutions; De Jong, M., Lalenis, K., Mamadouh, V.D., Eds.; Springer: Berlin, Germany, 2002; pp. 1-18.

14. Dequech, D. Institutions, social norms, and decision-theoretic norms. J. Econ. Behav. Organ. 2009, 72, 70-78. [CrossRef]

15. De Jong, M.; Mamadouh, V.D. Two contrasting perspectives on institutional transplantation. In The Theory and Practice of Institutional Transplantation: Experiences with the Transfer of Policy Institutions; De Jong, M., Lalenis, K., Mamadouh, V.D., Eds.; Springer: Berlin, Germany, 2002; pp. 19-32.

16. Lalenis, K.; De Jong, M.; Mamadouh, V.D. Families of nations and institutional transplantation. In The Theory and Practice of Institutional Transplantation: Experiences with the Transfer of Policy Institutions; De Jong, M., Lalenis, K., Mamadouh, V.D., Eds.; Springer: Berlin, Germany, 2002; pp. 33-54.

17. Macaes, B. Belt and Road: A Chinese World Order; C. Hurst \& Co.: London, UK, 2018; pp. 3-8. 
18. Brautigam, D.; Tang, X. Going global in groups: Structural transformation and China's special economic zones overseas. World Dev. 2014, 63, 78-91. [CrossRef]

19. Xu, H.; Chen, X.; Bo, Y. The Green Silk Road Economic Belt and the governance of the Aral Sea. China 2018, 16, 90-106.

20. Menhas, R.; Mahmood, S.; Tanchangya, P.; Safdar, M.N.; Hussain, S. Sustainable development under Belt and Road Initiative: A case study of China-Pakistan Economic Corridor's socio-economic impact on Pakistan. Sustainability 2019, 11, 6143. [CrossRef]

21. Tracy, E.F.; Shvarts, E.; Simonov, E.; Babenko, M. China's new Eurasian ambitions: The environmental risks of the Silk Road Economic Belt. Eurasian Geogr. Econ. 2017, 58, 56-88. [CrossRef]

22. Ascensao, F.; Fahrig, L.; Clevenger, A.P.; Corlett, R.T.; Jaeger, J.A.; Laurance, W.F.; Pereira, H.M. Environmental challenges for the Belt and Road Initiative. Nat. Sustain. 2018, 1, 206-209. [CrossRef]

23. Hanlon, R.J. Thinking about the Asian Infrastructure Investment Bank: Can a China-Led development bank improve sustainability in Asia? Asia Pac. Policy Stud. 2017, 4, 541-554. [CrossRef]

24. Thees, H. Towards local sustainability of mega infrastructure: Reviewing research on the New Silk Road. Sustainability 2020, 12, 10612. [CrossRef]

25. Chen, H.; Jiang, T.; Lin, C.; Zhao, H. Quantifying financing needs in the Belt and Road countries. Emerg. Mark. Financ. Trade. 2019, 55, 3178-3210. [CrossRef]

26. Yu, H. Reflections on the Belt and Road Initiative. China 2019, 17, 8-23.

27. Lai, K.P.; Lin, S.; Sidaway, J.D. Financing the Belt and Road Initiative (BRI): Research agendas beyond the "debt-trap" discourse. Eurasian Geogr. Econ. 2020, 61, 109-124. [CrossRef]

28. Brautigam, D.; Gallagher, K.P. Bartering globalization: China's commodity-backed finance in Africa and Latin America. Glob. Policy 2014, 5, 346-352. [CrossRef]

29. Liu, W.; Zhang, Y.; Xiong, W. Financing the Belt and Road Initiative. Eurasian Geogr. Econ. 2020, 61, 137-145. [CrossRef]

30. Aguirre, I. Making sense of para-diplomacy? An intertextual enquiry about a concept in search of a definition. Reg. Fed. Stud. 1999, 9, 185-209. [CrossRef]

31. Cornago, N. Diplomacy and para-diplomacy in the redefinition of international security: Dimensions of conflict and co-operation. Reg. Fed. Stud. 1999, 9, 40-57. [CrossRef]

32. Keating, M. Regions and international affairs: Motives, opportunities and strategies. Reg. Fed. Stud. 1999, 9, 1-16. [CrossRef]

33. Kincaid, J. The international competence of US states and their local governments. Reg. Fed. Stud. 1999, 9, 111-133. [CrossRef]

34. Happaerts, S. Are you talking to us? How subnational governments respond to global sustainable development governance. Environ. Policy Gov. 2012, 22, 127-142. [CrossRef]

35. Plagemann, J.; Destradi, S. Soft sovereignty, rising powers, and sub-national foreign policy-making: The case of India. Globalizations 2015, 12, 728-743. [CrossRef]

36. Joenniemi, P.; Sergunin, A. Para-diplomacy as a capacity-building strategy: The case of Russia's northwestern subnational actors. Probl. Post Communism. 2014, 61, 18-33.

37. Casson, R.; Dardanelli, P. Local government para-diplomacy in the UK: The case of the Kent-Virginia project. Local Gov. Stud. 2012, 38, 599-614. [CrossRef]

38. Royles, E. Sub-state diplomacy: Understanding the international opportunity structures. Reg. Fed. Stud. 2017, 27, 393-416. [CrossRef]

39. Zheng, Y.N. Perforated sovereignty: Provincial dynamism and China's foreign trade. Pac. Rev. 1994, 7, 309-321. [CrossRef]

40. Liu, T.; Song, Y. Chinese paradiplomacy: A theoretical review. SAGE Open 2020, 10, 1-14. [CrossRef]

41. Kossa, M.; Lomaeva, M.; Saunavaara, J. East Asian subnational government involvement in the Arctic: A case for para-diplomacy? Pac. Rev. 2020. [CrossRef]

42. Mierzejewski, D. The role of Guangdong and Guangzhou's subnational diplomacy in China's Belt and Road Initiative. China 2020, 18, 99-119.

43. Summers, T. The Belt and Road Initiative in southwest China: Responses from Yunnan province. Pac. Rev. 2021, 34, 206-229. [CrossRef]

44. Liu, T.; Song, Y. Trajectories to becoming international relations actors in China's BRI Initiative: A comparative study of the Guangdong and Yunnan provinces. Pac. Rev. 2020. [CrossRef]

45. Chan, W.Y. The soft power and paradiplomacy of Hong Kong. Asian Educ. Dev. Stud. 2019, 8, 161-172. [CrossRef]

46. Shen, S. Borrowing the Hong Kong identity for Chinese diplomacy: Implications of Margaret Chan's World Health Organization election campaign. Pac. Aff. 2008, 81, 361-382. [CrossRef]

47. Sit, V.F.S.; Yang, C. Foreign-investment-induced Exo-Urbanisation in the Pearl River Delta, China. Urban Stud. 1997, 34, 647-677. [CrossRef]

48. Chan, F. The Guangdong-Hong Kong-Macao Greater Bay Area: Enhancing collaborative governance of the CEPA implementation and regional integration. China 2020, 18, 171-191.

49. Belt and Road Initiative Hong Kong. Hong Kong's Participation. Available online: https://www.beltandroad.gov.hk/ participation.html (accessed on 27 November 2020).

50. Belt and Road Summit. Who Should Attend. Available online: http://www.beltandroadsummit.hk/en/participants/whoshould-participate.html (accessed on 27 November 2020). 
51. HKMA Infrastructure Financing Facilitation Office. HKMA Infrastructure Financing Facilitation Office. Available online: https: //www.iffo.org.hk/docs/default-source/factsheet/iffo-factsheet-(jun-2019-web-accessible).pdf?sfvrsn=d088c2ab_2 (accessed on 27 November 2020).

52. Hong Kong Monetary Authority. Infrastructure Financing: Belt and Road Strategy and Hong Kong's Role. Available online: https:/ / www.hkma.gov.hk/eng/news-and-media/insight/2016/04/20160407/ (accessed on 27 November 2020).

53. Hong Kong Monetary Authority. Dominant Gateway to China. Available online: https://www.hkma.gov.hk/eng/key-functions/ international-financial-centre/hong-kong-as-an-international-financial-centre/dominant-gateway-to-china/ (accessed on 27 November 2020).

54. Hong Kong Trade Development Council. HK Advantages. Available online: https://beltandroad.hktdc.com/en/hong-kongadvantages (accessed on 27 November 2020).

55. Reuters. China's Xi Says Belt and Road Must be Green, Sustainable. Available online: https://www.reuters.com/article/uschina-silkroad-idUSKCN1S104I (accessed on 17 January 2021).

56. UN Environment Programme. The Belt and Road Initiative International Green Development Coalition (BRIGC). Available online: https:/ / www.unenvironment.org/regions/asia-and-pacific/regional-initiatives/belt-and-road-initiative-internationalgreen\#: \{\}:text=The \%20Belt \%20and\%20Road\%20Initiative $\% 20$ presents $\% 20$ a $\% 20$ window $\% 20$ of $\% 20$ opportunity, achieve $\% 20$ the $\% 20$ Sustainable $\% 20$ Development $\% 20$ Goals.\&text=UN\%20Environment $\% 20$ will $\% 20$ also $\% 20$ be,counterparts $\% 20$ to $\% 20$ support\%20green\%20investment (accessed on 27 November 2020).

57. Hong Kong Monetary Authority. Green Bond Market: Hong Kong's Unique Role. Available online: https:/ /www.hkma.gov.hk/ media/eng/publication-and-research/quarterly-bulletin/qb201809/fa1.pdf (accessed on 27 November 2020).

58. Hong Kong Government. International Dispute Resolution Centre. Available online: https://www.legalhub.gov.hk/eng/idrc. html (accessed on 27 November 2020).

59. Transparency International. Corruption Perceptions Index 2019. Available online: https://images.transparencycdn.org/images/ 2019_CPI_Report_EN.pdf (accessed on 27 November 2020).

60. Hong Kong Government. The 2013 Policy Address. Available online: https://www.policyaddress.gov.hk/2013/eng/pdf/PA201 3.pdf (accessed on 27 November 2020).

61. South China Morning Post. New ID Card will Give Hong Kong, Macau and Taiwan Residents Same Access to Public Services as Mainland Chinese Counterparts. Available online: https:/ / www.scmp.com/news/hong-kong/politics/article/2159989/new-idcard-will-give-hong-kong-macau-and-taiwan-residents (accessed on 27 November 2020).

62. South China Morning Post. How a Hong Kong-Run Hospital in China Offers Cure for Nation's Sickly, Corrupt Health Care System. Available online: https://www.scmp.com/magazines/post-magazine/long-reads/article/2104224/how-hong-kongrun-hospital-china-offers-cure (accessed on 27 November 2020).

63. Constitutional and Mainland Affairs Bureau. Policy Areas-Education. Available online: https://www.bayarea.gov.hk/en/ opportunities/education.html (accessed on 17 November 2020).

64. Qianhai. Bonded Bay Area. Available online: http://www.szqh.com.cn/Why_Bonded_Bay_rea/index.html (accessed on 17 November 2020).

65. China Banking News. Shenzhen's Qianhai New District Flags Cancellation of Entry Restrictions for Foreign Investors. Available online: http:/ / www.chinabankingnews.com/2020/09/03/shenzhens-qianhai-new-district-flags-cancellation-of-entryrestrictions-for-foreign-investors / (accessed on 27 November 2020).

66. Qianhai. Legal Environment. Available online: http://www.szqh.com.cn/Why_Legal_Environment/index.html (accessed on 27 November 2020).

67. South China Morning Post. Xi Jinping Calls on Shenzhen to Create "Another Miracle" in Next Stage of Reform. Available online: https:/ / www.scmp.com/news/china/politics/article/3105519/xi-exhorts-shenzhen-step-and-lead-china-out-pandemicinnovation (accessed on 27 November 2020).

68. Baker McKenzie. National Security Law in Hong Kong. Available online: https:/ /www.bakermckenzie.com/- /media / files / insight/publications/2020/07/hong-kong-national-security-law-summary_160720.pdf (accessed on 27 November 2020).

69. Kaeding, M.P. The rise of "localism" in Hong Kong. J. Democr. 2017, 28, 157-171. [CrossRef]

70. China Daily. Full Text of President Xi's Speech at BRICS Business Forum in South Africa. Available online: http://www. chinadaily.com.cn/a/201807/26/WS5b5a80e3a31031a351e90857.html (accessed on 17 January 2021).

71. Wang, X.; Xiao, H.; Cheng, J. Sustainable Development Report: Evidence from Countries Along the "Belt and Road"; Economy \& Management Publishing House: Beijing, China, 2018; pp. 531-535.

72. World Bank Group. Reducing Environmental Risks from Belt and Road Initiative Investments in Transportation Infrastructure. Available online: http://documents1.worldbank.org/curated/en/700631548446492003/pdf/WPS8718.pdf (accessed on 17 January 2021).

73. OECD. China's Belt and Road Initiative in the Global Trade, Investment and Finance Landscape. Available online: https://www. oecd.org/finance/Chinas-Belt-and-Road-Initiative-in-the-global-trade-investment-and-finance-landscape.pdf (accessed on 17 January 2021). 